\title{
Pembatalan Izin Poligami di Pengadilan Tinggi Agama Maluku Utara
}

\author{
Rugaya Alkatiri \\ Institut Agama Islam Negeri (IAIN) Ternate \\ Abu Sanmas \\ Institut Agama Islam Negeri (IAIN) Ternate
}

\begin{abstract}
Abstrak
Penelitian ini dilakukan untuk Menganalisis dan Mengoreksi putusan No: 41/Pdt.G/2007/PA.Tte dan Putusan No: 12/Pdt.G/2007/PTA.MU, yang menjadi pertimbangan Hakim Pengadilan Agama Ternate dan Pengadilan Tinggi Agama Maluku Utara terhadap Putusan atas Perkara Izin Poligami yang terjadi di Propinsi Maluku Utara. Metode Penelitian yang di Gunakan adalah Penelitian Kepustakaan, yaitu: Kegiatan untuk memperoleh Informasi yang relevan dengan Pertimbangan Hakim Pengadilan Agama Ternate dan Pengadilan Tinggi Agama Maluku Utara terhadap putusan Perkara Izin Poligami. Hasil penelitian ini bahwa perkara Pemohonan Izin Poligami yang diajukan F.A. yang berkedudukan sebagai Pemohon, dimana Hakim pada Tingkat Pertama melihat pada Duduk Perkara serta Pertimbangan Hukumnya, sehingga Majelis Hakim pada Pengadilan Tingkat Pertama mengabulkan Permohonan Izin Poligami. Sedangkan pada Pengadilan Tingkat Banding yang diajukan oleh M.A yang berkedudukan sebagai Termohon pada Tingkat Pertama, namun dalam Tingkat Banding M.A berkedudukan sebagai Pembanding, namun dalam Putusan Majelis Hakim pada Tingkat Banding dengan melihat pada Duduk Perkara serta Pertimbangan Hukumnya bahwa Putusan pada Tingkat Pertama tidak dapat diterima dengan alasan perkara Permohonan Poligami merupakan Perkara yang bersifat Voluntair (sepihak) bukan Contentiosa (memiliki lawan dimana adanya Termohon yakni Isteri Pertama) kemudian perkara tersebut dianggap Obscur Libel (Kabur), karena Kuasa Hukumnya tidak mencantumkan siapa nama Calon Isterinya Pemohon atau Terbanding tersebut dalam isi Permohonan pada Tingkat Pertama serta pada Kontra Memori Banding sehingga Majelis Hakim memutuskan Perkara tersebut tidak dapat diterima.
\end{abstract}

Kata Kunci: Analisis, Putusan Pengadilan, Banding, Izin Poligami.

\section{Abstract}

This study was conducted to Analyze and Correct the verdict No: 41/Pdt.G/2007/PA. Tte and Verdict No: 12/Pdt.G/2007/PTA. MU, which is the consideration of the Judges of the Ternate Religious Court and the North Maluku Religious High Court against the Verdict on polygamy permit cases that occurred in North Maluku Province. The Research Method used is Literature Research, namely: Activities to obtain Information relevant to the Consideration of judges of the Ternate Religious Court and the North Maluku Religious High Court against the ruling of polygamy permit cases. The result of this study is that the case of the Polygamy Permit Application filed by the F.A. who is domiciled as the Applicant, where the Judge in the First Level looks at the Sitting Case and Its Legal Considerations, so that the Panel of Judges in the First Level Court granted the Polygamy Permit Application. While at 
the Court of Appeal filed by M.A. who is domiciled as the Respondent at the First Level, but in the Appeal Level M.A domiciled as a Comparison, but in the Decision of the Panel of Judges at the Appeal Level by looking at the Sitting Case and Legal Considerations that the Verdict at the First Level is not acceptable on the grounds that the polygamy application case is a Case that is Voluntair (unilateral) not Contentiosa (has opponents where The existence of the Respondent, the First Wife) then the case is considered Obscur Libel (Escape), because the Lawyer does not include the name of the Prospective Wife of the Applicant orbanding in the contents of the Application at the First Level and on the Counter Memory Appeal so that the Panel of Judges decides the Case is unacceptable.

Keywords: Analysis, Court Ruling, Appeal, Polygamy Permit.

\section{A. Pendahuluan}

Pada hakekatnya perkawinan bertujuan untuk mewujudkan keluarga yang bahagia dan kekal, dalam arti bahwa hubungan antara suami dan istri dalam perkawinan tersebut tetap utuh sampai ajal menjemput. ${ }^{1}$ Dalam perjalanannya kemudian dalam membangun bahtera rumah tangga terkadang terjadi dinamika, dan salah satu dinamika yang sering terjadi adalah dengan adanya pernikahan seorang laki-laki dengan 2 perempuan atau lebih, atau apa yang disebut dengan poligami.

Poligami merupakan salah satu persoalan dalam perkawianan yang menjadi isu paling kontrovisal dan masih dibicarakan dari dahulu hingga sekarang. Diskursus tentang poligami dibangun berdasarkan argumentasi yang bersifat religius, psikologis, normatif bahkan dikaitkan dengan isu gender, dimana poligami selalu "diidentikkan" dengan ketidak adilan gender. Dilain sisi, beberapa pihak yang mendukung menganggap bahwa poligami memiliki sandaran normatif yang tegas dan dipandang sebagai salah satu alternatif untuk menyelesaikan fenomena selingkuh dan prostitusi. ${ }^{2}$

Isu poligami terkadang menjadi senjata bagi pihak yang "anti-pati" terhadap agama Islam dengan mendeskripsikan poligami sebagai ajaran Islam dan gambaran bahwa perkawinan dalam Islam sangat mendeskreditkan kaum perempuan. Jika diteliti lebih jauh Poligami sendiri sebenarnya sudah ada sebelum Islam datang,

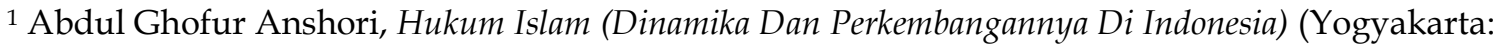
Kreasi Total Media, 2008).

${ }^{2}$ Amir Nurudin Azhari Akmal Tariga, Hukum Perdata Islam Di Indonesia, Studi Kritis Perkembangan Hukum Islam Dan Fikih, UU No. 1 Tahun 1974 Sampai KHI, 3rd ed. (Jakarta: Kencana, 2006).
} 
sehingga kurang tepat rasanya jika mengatakan poligami merupakan "Ajaran" Islam, meskipun benar bahwa Islam membolehkan poligami dengan batasan dan syarat tertentu. Al-Qur'an menggambarkan bahwa dalam hukum Islam pada dasarnya membolehkan poligami dengan catatan akan batasan wanita yang boleh dinikahi dalam poligami sebanyak empat wanita, dan dengan penegasan untuk berbuat adil diantara keempatnya. ${ }^{3}$

Bagi Ummat Islam di Indonesia, hukum yang mengikat bukan hanya hukum agama saja, namun ada hukum positif yang berlaku secara nasional yang mengikat warga negara Indonesia apapun agamanya. Mengenai pernikahan hukum yang positif yang mengikat tersebut berbentuk Undang-Undang Nomor 1 Tahun 1974 tentang Perkawinan sebagaimana Pasal 3 ayat 1 UU No. 1 tahun 1974 yang menyatakan bahwa pada azasnya dalam suatu perkawinan seorang pria hanya boleh mempunyai seorang isteri. Seorang wanita hanya boleh mempunyai seorang suami. ${ }^{4}$ Yang artinya bahwa hukum positif di Indonesia mengenai pernikahan menganut azas monogami.

Namun menurut M. Yahya Harahap, Asas monogami dalam UU No. 1 Tahun 1974 bukanlah asas monogami mutlak, namun asas monogami terbuka, yang artinya masih tetap membuka kemungkinan untuk tetap terjadinya poligami, dengan persyaratan tertentu. ${ }^{5}$ Poligami tetap terbuka untuk dilakukan dengan catatan dilakukan pada status hukum darurat (emergency law), atau dalam keadaan luar biasa (extra ordinary circumstance). ${ }^{6}$ Hal terebut tergambar dari Pasal 3 ayat 2 UU No. 1 tahun 1974 yang menyatakan bahwa Pengadilan, dapat memberi izin kepada seorang suami untuk beristeri lebih dari seorang apabila dikehendaki oleh fihakfihak yang bersangkutan. ${ }^{7}$

Di Kota Ternate ada suatu perkata Permohonan Izin Poligami yang telah mendapatkan putusan lewat Putusan Pengadilan Agama Ternate NO :

\footnotetext{
${ }^{3}$ Abdul Ghofur Anshori, Peradilan Agama Di Indonesia Pasca UU No. 3 Tahun 2006 Sejarah, Kedudukan Dan Kewenangan, 1st ed. (Yogyakarta: UII Press, 2007).

${ }^{4}$ Presiden Republik Indonesia, Undang-Undang Nomor 1 Tahun 1974 Tentang Perkawinan (Indonesia, 1974).

${ }^{5}$ Yahya Harahap, Hukum Perkawinan Nasional (Medan: Medan Zahir Trading Co, 1975).

${ }^{6}$ Ibid.

${ }^{7}$ Republik Indonesia, Undang-Undang Nomor 1 Tahun 1974 Tentang Perkawinan.
} 
41/Pdt.G/2007/PA.Tte Tentang Permohonan Perkara Izin Poligami yang memberi izin pihak "pemohon" untuk melakukan praktek poligami. Hakim dalam pengadilan yang mengadili permohonan izin poligami tersebut menganggap bahwa izin poligami telah sesuai dengan keadaan dan peruntukannya (Pasal 4 ayat 2 UU No. 1/1974 dan dalam Pasal 57 KHI). Namun kemudian Putusan Pengadilan Agama Ternate NO : 41/Pdt.G/2007/PA.Tte Tentang Permohonan Perkara Izin Poligami tersebut dibatalkan oleh Putusan Pengadilan Tinggi Agama Maluku Utara Nomor : 12/Pdt.G/2007 PTA .MU Yang Membatalkan Putusan Pengadilan Agama Ternate NO : 41/Pdt.G/2007/PA.Tte Tentang Permohonan Perkara Izin Poligami dimana Pertimbangan Hukum, Hakim Pengadilan Tinggi Agama Maluku Utara menimbang bahwa Perkara yang diajukan merupakan Perkara Voluntair sehingga Perkara tersebut bersifat Sepihak yakni hanya ada pihak Pemohon saja tidak ada orang lain yang di Tarik sebagai pihak Termohon, kemudian bahwa dalam Permohonan Izin Poligami, Pemohon/Terbanding tidak pernah menyatakan siapa calon Isteri kedua Pemohon/terbanding sehingga Majelis Hakim berpendapat bahwa Permohonan Izin Poligami Pemohon/Terbanding dinyatakan Kabur (Obscur Libel).

Oleh sebab itu, penelitian ini berfokus pada bagaimana Analisis Hakim Pengadilan Agama Ternate dalam Putusan No. 41/Pdt.G/2007/PA.Tte, tentang perkara Permohonan Izin Poligami ? dan kemudian dikomparasi kan dengan Analisis Hakim Pengadilan Tinggi Agama Maluku Utara dalam Putusan No. 12/Pdt.G/2007/PTA.MU tentang perkara Permohonan Izin Poligami.

Penelitian ini berjenis penelitian ini adalah penelitian Pustaka dengan menggunakan bahan hukum yuridis normatif. Penelitian hukum yuridis normatif adalah suatu penelitian dengan melakukan pengkajian terhadap studi dokumen, yaitu menggunakan berbagai data sekunder atau bahan pustaka. ${ }^{8}$ Penelaahan sumber data menggunakan pendekatan Penelitian Normatif yaitu penelitian yang dilakukan dengan penelitian hukum dalam arti meneliti kaedah atau norma. Yang menyebutkan bagian obyek penelitian hukum normatif antara lain asas - asas hukum, sistematika hukum. Sedangkan dalam ilmu sosial berhubungan yang ada, meneliti kebenaran fakta, ilmu hukum bukan semata - mata meneliti tentang

\footnotetext{
${ }^{8}$ Bahder Johan Nasution, Metode Penilitian Ilmu Hukum (Bandung: Mandar Maju, 2008).
} 
berlaku tidaknya kaedah hukum, tentang apa yang seyogyanya dilakukan (prespektif). Dan Pendekatan Penelitian Yuridis yang merupakan Kaedah bahan data hukum sekunder yang terdapat antara lain dalam peraturan perundang undangan, yurisprudensi, bahan hukum primer, literatur kepustakaan (bahan hukum sekunder) dan juga istilah atau pengertian menyangkut dengan hukum biasanya di ambil dari dalam kamus hukum atau kamus bahasa Indonesia, kamus bahasa inggris dan bahan hukum tersier (ensiklopedia Islam). Maka untuk mendukung bahan hukum sekunder tersebut, penulis juga melakukan penelitian studi dokumen pada konsideran putusan untuk memperoleh bahan hukum primer dari subyek penelitian.

B. Tinjauan Umum Poligami di Indonesia

1. Pengertian Poligami

Secara terminology, poligami dapat diartikan dengan seorang laki-laki yang mempunyai lebih dari satu isteri. ${ }^{9}$ Di Indonesia poligami dipadankan dengan kata "madu" yang bermaksud bahwa adanya pengumpulan atau pemaduan dua perempuan atau lebih dalam satu lembaga. ${ }^{10}$ Dalam kamus bahasa Indonesia poligami adalah sistem perkawinan yang salah satu pihak memiliki atau mengawini beberapa lawan jenisnya dalam waktu bersamaan. ${ }^{11}$

\section{Alasan Poligami}

Azhar Basyir berpendapat bahwa kebolehan poligami dalam Islam merupakan bentuk watak dan kebutuhan (fitrah) manusia yang diakomodir dalam agama. ${ }^{12}$ Dalam Islam Poligami tidak hanya dipersepsikan sebagai pemuasan nafsu seksual bagi laki-laki, namun lebih kepada memenuhi kebutuan sosiologis dan biologis sekaligus menanamkan konsep pemuliaan terhadap hakhak kaum perempuan, bisa dibayangkan jika dibandingkan pada zaman praIslam, dimana seseorang lelaki bisa menikahi banyak wanita hampir tanpa batas,

\footnotetext{
9 Slamet Abidin and Aminuddin, Fikih Munakahat I (Bandung: Pustaka Setia, 1999).

10 Islah Gusmiah, Mengapa Nabi Muhammad SAW Berpoligami ? (Yogyakarta: Pustaka Marwa, 2007).

${ }^{11}$ Departemen Pendidikan Nasional, Kamus Besar Bahasa Indonesia (Jakarta: Balai Pustaka, 2003).

12 Ahmad Azhar Basyir, Hukum Perkawinan Islam (Yogyakarta: UII Press, 1990).
} 
sementara Islam membatasi dengan 4 (empat) orang wanita. Bisa dibayangkan jika perempuan-perempuan dinikmati tubuhnya tanpa dinikahi, bukankah posisi perempuan seperti barang habis pakai? Poligami bukan hanya menempatkan perempuan sebagai barang yang hanya bisa dipakai, namun poligami melahirkan tanggung jawab bagi lelaki untuk bertanggungjawab terhadap-isteriisterinya dengan menafkahi secara adil, sebagaimana yang digariskan Al-Qur'an.

Poligami juga menjadi alternatif pemecahan solusi bagi kondisi-kondisi tertentu dalam rumah tangga, oleh sebab itu asa monogami dalam Hukum Perkawinan di Indonesia bukan asas monogami Absolut namun asas monogami terbuka, dimana dalam kondisi-kondisi yang dibenarkan menurut undangundang poligami dapat dilakukan, adapaun kondisi-kondisi tersebut antara lain:
a. isteri tidak dapat menjalankan kewajibannya sebagai isteri;
b. isteri mendapat cacat badan atau penyakit yang tidak dapat disembuhkan;
c. isteri tidak dapat melahirkan keturunan. ${ }^{13}$

Abdurrahman merumuskan ada beberapa hal kondisi tertentu yang menurut fuqoha menjadi alasan pembenar untuk dilakukan poligami, diantaranya: ${ }^{14}$
a. Istri mengidap suatu penyakit yang berbahaya dan sulit disembuhkan;
b. Isrti terbukti mandul dan dipastikan secara medis tak dapat melahirkan;
c. Istri sakit ingatan;
d. Istri memiliki sifat buruk;
e. Istri minggat dari rumah;

f. Ketika terjadi ledakan populasi perempuan misalnya dengan sebab perang banyak laki-laki yang terbunuh;

g. Kebutuhan suami beristri lebih dari satu. Dan jika tidak dipenuhi menimbulkan kemudharatan di dalam kehidupan dan pekerjaan.

Selanjutnya dalam perkara Poligami ini, pengadilaan hanya dapat memberi izin apabila permohonan itu didasarkan pada alasan-alasan yang dibenarkan,

\footnotetext{
13 Republik Indonesia, Undang-Undang Nomor 1 Tahun 1974 Tentang Perkawinan.

14 Abdurrahman, Penjelansan Hukum-Hukum Allah (Syari'ah) (Jakarta: Rajawali Pers, n.d.).
} 
seperti yang ditentukan dalam pasal 4 ayat 241 (1), dan pasal $57 \mathrm{KHI}$, dengan uraian sebagi berikut: 15

a. Istri tidak dapat menjalankan kewajibannya sebagai isteri. Alasan ini memang dapat dibenarkan sebab bila dikembalikan pada ketentuan pasal 1 bahwa perkawinan itu bertujuan membentuk keluarga (rumah tangga) yang bahagia dan kekal, maka dengan tidak dapatnya isteri menjalankan kewajibanya sebagai isteri, ini berarti hak-hak suami dalam rumah tangga tidak terpenuhi. Dalam hal ini, dapat menghalangi tercapainya tujuan perkawinan seperti tersebut diatas. Tetapi dalam menilai isteri tidak dapat melaksanakan kewajibanya sebagai istri, akibat tindakan suami itu sendiri yang dapat menuntut haknya saja tanpa memperhatikan dan melaksanakan kewajibanya dengan semestinya. Dalam hal seperti ini tentu saja kesalahan tidak dapat ditimpakan kepada isteri.

b. Isteri mendapat cacat badan atau penyakit yang tidak dapat disembuhkan. alasan ini adalah semata mata berdasarkan alasan kemanusiaan sebab bagi suami tentu saja yang dapat menderita lahir batin selama hidupnya apabila hidup bersama dengan isteri yang dalam keadaan demikian. Tetapi sebaliknya menceraikan isteri yang demikian di mana keadaan isteri betul betul dalam keadaan yang membutuhkan pertolongan adalah suatu perbuatan yang bertentangan dengan kemanusiaan. Oleh karena itu dilaksanakan Poligami dalam hal seperti ini di pandang lebih berperi kemanusiaan dari pada mengejar monogamy dengan tindakan menceraikan isteri yang sedang dalam penderitaan dan membutuhkan pertolongan dan perlindungan dari seorang suami, Apabila isteri tidak dapat memperoleh keturunan. Alasan ini adalah alasan yang wajar, sebab memperoleh keturunan adalah merupakan salah satu tujuan dari perkawinan itu sendiri, dan bagi manusia yang normal tentu menghendaki keturunan dalam suatu

\footnotetext{
15 Soemiyati, Hukum Perkawinan Islam Dalam Undang-Undang Perkawinan (Undang- Undang Nomor 1
} Tahun 1974 Tentang Perkawinan), 4th ed. (Yogyakarta: Liberty, 2003). 
perkawinan. Tentu pengunaan alasan ini dalam memberikan keterangan yang jelas dari seorang ahli, apakah kemandulan benarbenar berasal dari pihak isteri. sebab kemandulan itu dapat juga berasal dari pihak suami maupun dari pihak isteri. Apabila ternyata kemandulan ini berasal dari pihak isteri maka alasan ini dapat diterima.

Dengan alasan-alasan di atas UU 1/1974 dn KHI), seorang laki-laki dapat mengajukan permohonan izain poligami kepada pengadilan agama. ${ }^{16}$ Selain itu ada pemenuhan kewajiban yang harus dipenuhi dalam melakukan poligami, yakni keadilan, keadilan yang dimaksud adalah mampu mencukupi nafkah semua keluarga dan bersikap adil dalam pemberian nafkah lahir dan giliran waktu tinggalnya. ${ }^{17}$

\section{Syarat Izin Poligami}

Menurut UU No. 1/1974 syarat-syarat untuk mengajukan izin poligami adalah sebagai berikut: 18

a. adanya persetujuan dari isteri/isteri-isteri;

b. adanya kepastian bahwa suami mampu menjamin keperluankeperluan hidup isteri-isteri dan anak-anak mereka;

c. adanya jaminan bahwa suami akan berlaku adil terhadap isteri-isteri dan anak-anak mereka.

Secara teknis, syarat-syarat tersebut dapat dijelaskan sebagai berikut:

a. Adanya persetujuan dari isteri/isteri-isteri yang terdahulu. Persetujuan ini boleh tertulis dan boleh dinyatakan secarah lisan didepan sidang pengadilan. Untuk menghindari hal-hal yang tidak diinginkan misalnya, pemalsuan surat persetujuan apabila itu tertulis, maka pengadilan sebaiknya harus mendengar langsung dari isteri tersebut di depan siding;

16 Zainuddin Ali, Hukum Perdata Islam Di Indonesia (Jakarta: Sinar Grafika, 2006).

${ }^{17}$ Abdul Rahman Ghozali, Fiqih Munakahat (Jakarta: Kencana Prenada Media Group, 2012).

${ }_{18}$ Republik Indonesia, Undang-Undang Nomor 1 Tahun 1974 Tentang Perkawinan. 
b. Didasarkan pada surat keterangan penghasilan suami yang tanda tangani oleh bendaharawan tempat suami bekerja, atau dapat di lihat dari keterangan pajak penghasilan atau surat-surat keterangan lain yang dapat di terima oleh pengadilan. Jadi kepastian yang di maksud dalam ketentuan ini adalah suatu penilaian hakim berdasarkan kekayaan pemohon yang ada pada saat permohonan di anjurkan bukan kepastian yang bersifat mutlak;

c. Adanya jaminan bahwa suami dapat melakukan adil terhadap isteri-isteri dan anak-anak mereka. Untuk menentukan adanya jaminan atau tidak dari suami untuk berlaku adil terhadap isteri-isteri dan anak-anak mereka adalah sukar, maka yang segera dapat di lakukan oleh hakim ialah meminta surat pengakuan atau surat pernyataan bahwa suami mengaku dapat berlaku adil terhadap isteri-isteri dan anak-anak mereka. Kemudaian apabila seorang suami menyalahi ikrar jaminan berlaku di diskriminasikan, maka dapat menutup pemulihan itu pada Pengadilan.

Berdasarkan hal tersebut untuk menghindari agar tidak terjadi salah satu pihak merasa di rugikan dengan adanya perkawinan itu, maka di perlukan jaminan bahwa suami dapat berlaku adil terhadap isteri-isteri dan anak anak mereka dengan pernyataan atau janji dari suami yang di buat dalam bentuk yang di tetapkan untuk itu. Pernyataan atau janji itu harus di ucapkan dalam persidangan Majelis Hakim. ${ }^{19}$

Menurut pandangan Normatif al-Qur'an yang selanjutnya di adopsi oleh ulama - ulama fikih setidaknya menjelaskan dua persyaratan yang harus di miliki suami di antaranya : pertama, seoranga laki - laki yang akan berpoligami harus memiliki kemampuan dana yang cukup untuk membiayai bersbagai keperluan dengan bertambahnya isteri yang di nikahi; kedua, seorang lelaki harus memperlakukan semua isterinya dengan adil. Tiap isteri harus di perlakukan sama dalam memenuhi hak perkawinan serta hak hak lain. ${ }^{20}$ di

\footnotetext{
19 Ibid.; Direktorat Pembinaan Badan Peradilan Agama, Kompilasi Hukum Islam.

20 Ibn Hajar Al-Asqalani, Bulughul Maram Min Adillatil Ahkam, ed. Muhammad Thalib, 2nd ed.

(Bandung: Gema Risalah Press, 1996).
} 
samping itu pembolehan ini di berikan dengan pembatasan pembatasan yang berat, berupa syarat syarat dan tujuan yang mendesak diantaranya :21

a. Jumlah wanita yang boleh di kawini tidak boleh lebih dari empat orang;

b. Sanggup berlaku adil terhadap sama isteri - isterinya. Dan jika kemudian merasa tidak dapat sanggup berlaku adil terhadap semua isterinya, maka sebaiknya jangan kawin untuk kedua kalinya atau seterusnya;

c. Wanita yang di kawini sayangnya adalah mempunyai anak yatim, dengan maksud anak yatim tersebut berada di wiliyah pengawasan laki - laki yang berpoligami, sehingga suami dapat berlaku adil terhadap anak yatim tersebut;

d. Wanita - wanita yang hendak di kawini itu tidak boleh ada hubungan saudara, baik sedarah ataupun sepupuan.

\section{Prosedur Poligami}

Prosedur Poligami menurut pasal 40 Peraturan Pemerintah No. 91974 menyebutkan bahwa apabila seorang suami bermaksud untuk beristeri lebih dari seorang, maka ia wajib mengajukan secara tertulis kepada pengadilan. Hal tersebut di atur lebih lanjut dalam pasal 56, dan 58 kompilasi hukum Islam. ${ }^{22}$ Apabila pengadilan agama sudah menerima permohonan poligami, maka kemudian mereka memeriksa berdasarkan ketentuan hukum, maka apabila terjadi sesuatu dan lain hal, isteri atau isteri tidak dapat dimita persetujuannya atau tidak dapat menjadi pihak dalam perjanjian, undang - undang No. 1 tahun 1974 pasal 5 ayat 2. di sandingkan juga pasal 58 KHI. Kemudian apabila Pengadilan berpendapat bahwa, sudah cukup alasan bagi Pemohon tidak untuk beristeri lebih dari seorang. ${ }^{23}$ Oleh karena itu, poligami bukan semata - mata urusan pribadi, tetapi juga menjadi urusan kekuasaan negara yakni semestinya ada "izin" pengadilan agama, bila tidak ada izin, maka perkawinan di anggap "poligami liar" atau tidak sah dan tidak mengikat. Maka perkawinan tetap

${ }^{21}$ Slamet Abidin and Aminuddin, Fiqih Munakahat II (Bandung: Pustaka Setia, 2009).

${ }^{22}$ Abdurrahman, KHI Di Indonesia (Jakarta: Akademika Pressindo, 1992).

${ }^{23}$ Soemiyati, Hukum Perkawinan Islam Dalam Undang-Undang Perkawinan (Undang- Undang Nomor 1

Tahun 1974 Tentang Perkawinan). 
dianggap "never existed" tanpa izin pengadilan agama, meskipun perkawinan di lakukan di hadapan PPN (Pasal 8 UU.1/1974 Perkawinan dilarang antara dua orang yang : (1) hubungan darah dengan keturunan garis keturunan lurus kebawah ataupun keatas). ${ }^{24}$ untuk menjaga dan menghindari kebolehan kawin poligami tidak dilaksanakan oleh laki - laki yang kurang mendalami maksud dan tujuan perkawinan menurut ajaran Islam, atas dasar " Mursalah - Mursalah", maka, negara dibenarkan mengadakan penertiban, tetapi tidak berkencenderungan untuk menutup rapat pintu poligami. undang - undang perkawinan No. 1 tahun 1974 pasal 3, 4 dan 5 yang menentukan bahwa perkawinan berasas monogami, tetapi membuka jalan untuk berpoligami atas izin pengadilan serta mampu memberikan nafkah dan dapat berlaku adil. Sebagaimana yang telah dijelaskan sebelumnya pada pasal 4 ayat 2 .

Pada dasarnya aturan pembatasan, penetapan syarat syarat dan kemestian campur tangan Penguasa yang telah di atur dalam UU No. 1 tahun 1974 diambil alih seluruhnya oleh KHI. Keberanian KHI mengambil alih aturan tersebut merupakan langkah maju secara dinamis aktualisasi hukum Islam di bidang poligami. Keberanian untuk mengaktualkan dalam membatasi kebebasan poligami di dasarkan atas alasan ketertiban umum. Lagi pula, jika diperhatikan ketentuan Al-quran surat An-Nisa ayat 3 tersebut, tingkat derajat hukum perkawinan poligami adalah "kebolehan" itu pun kalau di telusuri sejarahnya tergantung pada situasi dan kondisi masa permulaan Islam. Dengan demikian; pertama, poligami harus di dasarkan pada alasan yang enumerative (satu prsatu disebutkan alasan Poligami. Tanpa di penuhi salah satu alasan tak boleh berpoligami; kedua, harus memenuhi syarat yang telah di tentukan; dan ketiga, harus ada izin dari pengadilan agama. ${ }^{25}$

Setiap pilihan, baik monogami maupun poligami, memiliki implikasi positiif di samping membawa konsekuensi resiko negatif. Karena ummat manusia secara fitrah mempunyai potensi positif dan negative dari kedua kecenderungan tersebut. Adanya potensi watak cemburu kaum wanita, iri hati dan suka

\footnotetext{
${ }^{24}$ Republik Indonesia, Undang-Undang Nomor 1 Tahun 1974 Tentang Perkawinan.

${ }^{25}$ Ali, Hukum Perdata Islam Di Indonesia.
} 
mengeluh yang muda timbul dari dalam kehidupan keluarga poligami. Maka dengan demikian, poligami secara empiris memang dapat menjadi sumber konflik antara suami dan istri serta anak - anak dari istri - istrinya, maupun konflik antara istri dan istri serta anak - anaknya masing - masing. ${ }^{26}$

Dari beberapa uraian tentang persoalan poligami di atas, dapatlah dipahami bahwa, pengajuan suami untuk melakukan poligami dengan alasan Istri tidak dapat menjalankan kewajibannya, alasan itu berkaitan dengan Istri tidak dapat menjalankan kewajibannya maka demikian; pertama dengan kalimat " tidak dapat secara mutlak", sedangkan kedua Kalimat " tidak dapat lagi " suami yang bermaksud poligami harus menegakkan syarat utama, yakni menjamin keadilan, dengan cara mengatur Nafkah Lahir dan Batin secara seimbang serta pertimbangan kemanusiaan dan derajatnya sama dengan kedudukan istri lainnya sesuai dengan Hukum dan perundangan yang berlaku. ${ }^{27}$ Masalah Poligami serumpun dengan masalah Perceraian, apabila di lihat dari segi sebab akibat dan peraturan. Perturan deri kedua masalah ini belum menunjukan titik kesempurnaan dari waktu kewaktu sehingga tidak mustahil bila di keluarkan undang - undang terhadap kedua masalah ini belum menunjukan titik kesempurnaan dari waktu kewaktu, sehingga tidak mustahil bila di keluarkan Undang - undang, terutama mengenai pengumuman sebab perceraian atau poligami yang dapat menimbulkan persangkaan buruk terhadap kaum wanita dan seluruh keluarganya.

Oleh karena itu, poligami bukan jalan keluar yang mudah bagi suami. Jika tatacara dan prosedurnya yang di tempuh oleh suami yang bermaksud poligami, dapat di benarkan, hal tersebut di menyebabkan istri - istrinya merasa di hargai oleh hukum dan Perundang - undangan yang berlaku. Maka jadilah seorang pemimpin rumah tangga yang baik dalam arti jujur, adil, beriman dan berbudi pekertiaa yang baik sebagaimnah yang telah dicontohkan oleh Rasulullah SAW,

${ }^{26}$ Ahmad Azhar Basyir and Dkk, Pengadilan Agama Islam Dan KHI Dalam Tata Hukum Indonesia, ed. Moh. Mahfud MD (Yogyakarta: UII Press, 1993).

27 Basyir, Hukum Perkawinan Islam. 
dalam memimpin ummat Islam dan keluarganya dengan penuh mawaddah dan rahma sampai akhir hayatnya.

\section{Profil Pengadilan Agama Kelas 1B Ternate}

Daerah Kabupaten Maluku Utara dari pulau dan waktu dahulu disebut Moloku Kie Raha atau Daerah raja - raja, dan dibagi atas 4 kesultanan serta masing masing diperintahkan oleh seorang sultan yang berstatus otonom yaitu : Ternate, Tidore, Bacan dan Jailolo. dalam Kepemerintahan Sultan Ternate dibantu oleh Jogugu. secara garis besar, seorang yang menempati posisi Jogugu (Mangkubumi) bertugas mewakili raja atau sultan dalam melaksanakan urusan pemerintahan yang tidak dilakukan secara langsung oleh mereka. ${ }^{28}$ Urusan Agama dan Hukum - Hukum Agama, Sultan dibantu oleh seorang khadi (orang yang alim). Khadi adalah seorang hakim yang membuat keputusan berdasarkan syariat Islam. Sultan sebagai penguasa tertinggi, jogugu (Mangkubumi) menjalankan perintah disamping sebagai Ketua Landrad yang disebut Pengadilan Suapraja, yang berwenang memeriksa dan mengadilai segala kepentingan umat islam yang meliputi urusan Tauliayah dan Hukumiyah: Nikah Talak Ruku, Pendidikan Agama Penerangan Agama, Penyuluhan Agama, da'wah, pendeknya sesuatu yang menyangkut Sunnah maupun fardu, dan selebihnya mengurus dan mengadili perkara perkara Ummat Islam ( Peradilan Agama).

Setelah RI mencapai kedaulatannya, maka Pemerintah Kesultanan kembali kepada Pemerintah Pusat, maka didaerah dikembalikan kepada Bupati d. h.i meliputi seluruh daerah Kabupaten Maluku Utara (Ternate, Tidore dan Bacan)Pengadilan Swapraja dibawa Pimpinan Jogugu dintergrasikan kepada Badan Peradilan Umum ( Pengadilan Negeri) sesuai pasal 39 UU. No. 14 tahun 1970. UU No. 1 tahun 1951 ayat (2) oleh Menteri Kehakiman secara berangsur angsur setelah dilakukan penghapusan Pengadilan Adat/ Swapraja diseluruh Bali, Sulawesi, Lombok, Sumbawa, Timor, Kalimantan, Jambi, dan Maluku “ Penghapusan tersebut Pengadilan / Hakim Syara Swapraja tidak turut terhapus dan Hakim Syara Swapraja ini tetap berjalan terus, hal mana berdasarkan atas pasal 134 (ayat 2) dari

${ }^{28}$ Mahid and Dkk, Sejarah Kerajaan Bungku (Yogyakarta: Ombak, 2012). 
Indiche Staats Regeling, karena dalam UUD 1945 tidak terdapat ketentuan mengenai Peradilan Agama. Bahkan dalam Pasal 1 ayat ( ayat 2) UU. No. 1 Th. 1951 menyatakan bahwa : jika Peradilan itu menurut hukum yang hidup merupakan satu bagian dari Peradilan Swapraja (Zelfbestuurs rachtspraak) tidak turut terhapus.

Dengan demikian, Hakim syara Swapraja berjalan terus walupun kemudian telah dibukanya Kantor Urusan Agama yang melakukan urusan-urusan : Tauliyah. Dengan Panatapan Menteri Agama RI No. 5 tahun 1958 telah dibentuk Peradilan Agama / Mahkamah Syariah termasuk di Ternate, Morotai, Soa-sio, serta Kep. Menag RI no. 87 tahun 1966 termaksud Pengadilan Agama/ mahkamah Syariah Labuha, dimana kesemuanya itu terdapat didalm wil. Kab. Maluku Utara, maka untuk menghilangkan dualism dalam urusan Peradilan Agama tersebut yakni Pengadilan Agama/ Mahkamah Syariah D.H.I Departemen Agama disatu pihak dan Hakim Syara Swapraja dilain pihak, maka atas prakarsa Sultan Muda Ternate MUDHAFAR SYAH, dan JOGUGU Dewan Adat Moloku di Ternate mengadakan serah terima badan Hakim Syara Swapraja tersebut kepada DIREKTORAT PERADILAN AGAMA DI JAKARTA yang sekaligus dijabat oleh Bapak K.H. Z.A NUCH. Dengan ketentuan bahwa Hakim Syara Swapraja di Ternate yang menurut ketentuan pasal 1 ayat (4) dari UU Darurat No. 1 tahun 1951 jo Peraturan Pemerintah No. 45 tahun 1957 tugas dan wewenang badan tersebut seharusnya sudah tampil dalam Pengadilan Agama/ Mahkamah Syaria'ah setempat, maka adanya penyerahan Badan Hakim Syara tersebut kepada DIREKTORAT PERADILAN AGAMA akan lebih menyempurnahkan dan menghapuskan dualism pelaksanaan tugas Peradilan Agama di Ternate serta daerah Maluku pada umumnya, bahwa berdasarkan pasal 39 UUD 1945 atas hak-hak asal usul dalam diri dai 4 Kesultanan dan 4 Kekhadian tadi, maka dibentuk 4 Pengadilan Agama/ Mahkamah Syariah Yaitu Ternate, Soasio, Labuha dan Morotai. Pengadilan Agama Ternate, pada tanggal 22 Agustus 1966 setelah adanya serah terima dari Badan Hakim Syara di Ternate dari Jogugu (Ketua Dewan Adat Moluku Sdr. K. H NUCH ( Kepada Kepala Direktorat Peradilan Agama di Jakarta. Kemudian penunjukan personil Pengadilan Agama Ternate adalah berdasarkan SK Menteri Agama Nomor : B/ IC//5593 tanggal 25 Oktober 1966 yang terdiri atas seorang Pejabat Ketua, 2 
(dua) orang Hakim Anggota tetap , 2 (dua) orang Hakim Anggota Honorer dan seorang Panitera;

D. Deskripsi Perkara Pengajuan Permohonan Izin Poligami di Pengadilan Agama Ternate Kelas IB dari Tahun 2007

Dari tahun 2007 Pengadilan Agama Ternate menerima Perkara yang masuk sebanyak 264 Perkara, dan dari sebanyak perkara yang masuk tersebut, Pengadilan sudah memutuskan perkara sebanyak termasuk di dalamnya berupa perkara Poligami sebanyak 218 perkara dan sisa perkara yang belum di putus sebanyak 46 perkara, jika dibandingkan dengan tahun tahun sekarang, perkara yang masuk pada tahun 2007 lebih minim dibandingkan dengan perkara yang masuk pada tahun sekarang hal ini di akibatkan masyarakat belum mengenal dunia teknologi pada tahun tersebut, karena kebanyakan masalah yang masuk ke Pengadilan Agama adalah diakibatkan karena perselingkuhan melalui transmisi Telepon seluler (HP) berikut tabel keadaan perkara dapat gambarkan sebagai berikut :

Tabel. 1

\begin{tabular}{|c|c|c|c|c|c|}
\hline No & \multicolumn{2}{|c|}{ JENIS PERKARA } & Perkara & Perkara & $\begin{array}{c}\text { Sisa } \\
\text { Perkar }\end{array}$ \\
\hline 1 & \multirow{8}{*}{ PERKAWINAN } & Izin Poligami & 1 & 1 & 0 \\
\hline 2 & & Cerai Talak & 109 & 88 & 21 \\
\hline 3 & & Cerai Gugat & 147 & 124 & 23 \\
\hline 4 & & Isbat Nikah & 0 & 0 & 0 \\
\hline 5 & & Harta Bersama & 0 & 0 & 0 \\
\hline 6 & & Hadhanah & 0 & 0 & 0 \\
\hline 7 & & Dispensasi Nikah & 0 & 0 & 0 \\
\hline 8 & & Wali Adhol & 0 & 0 & 0 \\
\hline
\end{tabular}




\begin{tabular}{|l|l|l|c|c|c|}
\hline 9 & & Kewarisan & 7 & 2 & 2 \\
\cline { 1 - 4 } & \multirow{2}{*}{ KEWARISAN } & Penetapan Ahli Waris & 0 & 0 & 0 \\
\cline { 3 - 5 } & & Ekonomi Syariah & 0 & 0 & 0 \\
\hline \multicolumn{2}{|l|}{ JUMLAH } & 264 & 218 & \\
\hline \multicolumn{2}{|r|}{} & & & \\
\hline
\end{tabular}

Sumber: Pengadilan Agama Kelas 1B Ternate

Dari Gambaran Tabel tersebut terlihat jelas bahwa Perkara Izin Poligami yang Penulis angkat tersebut dengan Nomor perkara : 41/Pdt.G/2007/PA.Tte telah di putus, dengan alasan Izin Poligami adalah Isteri Pertama tidak bisa memberikan keturunan selama kurang lebih masa Pernikahan 18 tahun. Dari Putusan Tersebut Istri dari Pemohon yang bernama Maryam yang berkedudukan sebagai Termohon dalam hal ini keberatan karena Termohon merasa tidak adil dengan Putusan Hakim dimana Si Termohon menghendaki Pemohon Menikah lagi kecuali saudara sepupunya sendiri, namun menurut Hakim alasan keberatan yang di ajukan si Termohon sangatlah tidak sesuai dengan ketentuan Hukum, Karena menurut Majelis Hakim jika Syarat Formil salah satunya Istri pertama memberikan Izin Poligami maka Majelis Hakim tetap mengabulkannya selama syarat alternatifnya tersebut terpenuhi dengan siapapun itu Pemohon menikah supaya menghindari adanya Perzinahan karena di satu sisi menurut Majelis Hakim Pemohon memang sudah memiliki Hubungan dengan calon isteri keduanya sebelum perkara izin Poligami tersebut terdaftar di Pengadilan Agama Ternate. Sehingga Termohon mengajukan Upaya Hukum Banding ke Pengadilan Tinggi Agama Maluku Utara dan upaya tersebut dikabulkan oleh Pengadilan Tingkat Banding dengan membatalkan Putusan Pengadilan Agama Ternate dengan Nomor perkara : 12/Pdt.G/2007/PTA.MU. dengan Produk hukumnya adalah penetapan.

Tabel. 2

\begin{tabular}{|c|c|c|c|c|c|c|}
\hline \multirow{3}{*}{$\begin{array}{c}\text { PENGADILAN } \\
\text { AGAMA } \\
\text { PENGAJU }\end{array}$} & \multicolumn{5}{|c|}{ KEADAAN PERKARA BANDING } & \multirow{3}{*}{$\begin{array}{c}\text { SISA } \\
(\%)\end{array}$} \\
\hline & SISA & PERKARA & JUMLA & PERKARA & SISA & \\
\hline & $\begin{array}{c}\text { AKHIR } \\
2006\end{array}$ & MASUK & $\mathrm{H}$ & PUTUS & & \\
\hline
\end{tabular}




\begin{tabular}{|c|l|c|c|c|c|c|c|}
\hline 1 & \multicolumn{1}{|c|}{2} & 3 & 4 & 5 & 6 & 7 & 8 \\
\hline 1 & TERNATE & 0 & 6 & 6 & 6 & 0 & 0 \\
\hline 2 & SOASIO & 0 & 0 & 0 & 0 & 0 & 0 \\
\hline 3 & MOROTAI & 0 & 1 & 1 & 1 & 0 & 0 \\
\hline 4 & LABUHA & 0 & 1 & 1 & 1 & 0 & 0 \\
\hline \multicolumn{2}{|c|}{ JUMLAH } & 0 & 8 & 8 & 8 & 0 & 0 \\
\hline
\end{tabular}

Sumber: Pengadilan Agama Kelas 1B Ternate

Rekapitulasinya dapat dirinci sebagai berikut :

1. Sisa Tahun $2006=0$ perkara;

2. Diterima Tahun $2007=8$ perkara;

3. Jumlah $=8$ perkara;

4. Diputus $=8$ perkara;

5. Sisa $=0$ perkara

Dari jumlah perkara Banding 8 yang diterima pada tahun 2007 tersebut, dapat dirinci menurut jenis perkaranya sebagai berikut :

1. Cerai Talak $=3$ perkara;

2. Cerai Gugat = 1 perkara;

3. Harta Bersama = 1 perkara;

4. Izin poligami $=1$ perkara;

5. Kewarisan $=2$ perkara

Dari data perkara Banding yang diterima Tahun 2007 menurut jenis perkaranya pada Pengadilan Tinggi Agama Maluku Utara sebagaimana tersebut diatas, yakni sejumlah 8 perkara yang diputus/diselesaikan pada Tahun 2007, dapat dirinci menurut jenis perkaranya sebagai berikut :

1. Cerai Talak = 3 perkara;

2. Cerai Gugat = 1 perkara;

3. Harta Bersama = 1 perkara;

4. Izin poligami $=1$ perkara;

5. kewarisan $=2$ perkara; 


\section{Sisa $=0$ perkara}

1. Pembahasan dan Analisis Putusan Pengadilan Agama Ternate Nomor 41/Pdt.G/2007/PA.Tte tentang Perkara Permohonan Izin Poligami.

Putusan Hakim atau Putusan Pengadilan merupakan aspek penting dan diperlukan untuk menyelesaikan Perkara Perdata ( Izin Poligami ). Keputusan Hakim berguna bagi Pemohon untuk mendapatkan kepastian hukum tentang permohonannya. Dalam menjatuhkan putusan, keputusan hakim harus mencerminkan keadilan, akan tetapi persoalan keadilan tidak akan berhenti dengan pertimbangan hukum semata - mata, melainkan persoalan keadilan biasanya dihubungkan dengan kepentingan individu atau para pencari keadilan, dan itu berarti keadilan menurut hukum sering diartikan dengan sebuah kemenangan dan kekalahan oleh pencari keadilan. Dimana para pencari keadilan yang dimaksud adalah pemohon dengan termohon.

Para ahli membedakan istilah dari seorang laki - laki yang mempunyai lebih dari seorang isteri dengan istilah poligini yang berasal dari kata polus berarti banyak dan gune berarti perempuan. Sedangkan bagi seorang isteri yang mempunyai lebih dari seorang suami disebut poliandri yang berasal dari kata polus yang berarti banyak dan andros berarti laki - laki. Dimana Poligini dan Poliandri merupakan dua bentuk Poligami.

Jadi, kata yang tepat bagi seorang laki - laki yang mempunyai isteri lebih dari seorang dalam waktu yang bersamaan adalah poligini bukan poligami. Meskipun demikian, dalam perkataan sehari - hari yang dimaksud dengan poligami itu adalah perkawinan seorang laki - laki dengan lebih dari seorang perempuan dalam waktu yang bersamaan, atau masyarakat pada umumnya menilai bahwa poligini adalah poligami.

Undang - Undang perkawinan No. 1 tahun 1974 dan KHI telah menjelaskan secara terperinci dalam pasal dari peraturan hukum tersebut, tetapi masih terdapat keganjalan di dalam konsideran putusan tersebut, sehingga dalam hal ini, Penulis mengganggap perlu diteliti dan dianalisis lebih lanjut, dengan menulusuri konsideran putusan Pengadilan Agama Ternate tersebut, guna mencari solusi dan titik kebenaran yang terbaik dengan menggunakan ketentuan 
hukum yang hidup dan berkembang dalam masyarakat yang beragama islam. Dalam hal ini, berdasarkan beberapa permasalahan pokok tersebut diatas, maka penyusun dapat mengkaji dan menganalisis putusan hukum perkara permohonan izin poligami tersebut dengan menggunakan metode penelitian kepustakaan atau studi dokumen, metode deduktif dan induktif dengan pendekatan Yuridis-Normatif .

Agama islam merupakan agama yang di dalamnya terdapat akidah (Keyakinan) dan Syari'ah (hukum) juga akhlak. Untuk itulah, menjadi suatu keniscayaan bahwa agar dapat mengetahui hukum islam secara benar maka terlebih dahulu harus mengerti tentang islam sebagai suatu agama yang menjadi induk dari segala aturan yang diterapkan pada manusia, termasuk hukum di dalamnya.

Islam adalah sebagai sebuah Institusi Agama, demi tegaknya Hukum Islam tidak dapat dipaksakan oleh lain pihak karena tiadanya kekuasaan yang dapat memaksakan kehendaknya. Adapun yang memiliki kekuasaan berikut alat pemaksanya adalah negara dan yang berkuasa dalam suatu negara yaitu Pemerintah. Pemerintahan (Eksekutif dan legislatif) melalui politiknya menetapkan hukum yang berlaku (hukum positif). Dengan demikian untuk dapat tegaknya hukum Islam secara sempurna, yang merupakan konsekuensi logis bagi umat Islam, menjadi sebuah keniscayaan untuk terbentuknya institusi pemerintahan islami yang dikenal dengan khilafah islamiah. Jika tidak demikian maka yang terjadi adalah penegakan hukum Islam secara parsial.

Dalam perumusan kaidah - kaidahnya dapat saja berubah sesuai dengan perubahan zaman. Dalam bidang ini dapat dilakukan modernisasi, asal saja modernisasi itu sesuai atau sekurang - kurangnya tidak bertentangan dengan jiwa hukum Islam pada umumnya, karena norma - norma dasar yang terdapat di dalam Al-Qur'an masih bersifat umum, demikian juga halnya dengan aturan yang ditentukan oleh Nabi SAW terutama mengenai muamalah, maka setelah Nabi SAW wafat, norma - norma dasar yang masih bersifat umum itu perlu dirinci lebih lanjut. Perumusan dan penggolongan norma - norma hukum dasar yang bersifat umum itu ke dalam kaidah - kaidah yang lebih konkrit, 
memerlukan disiplin ilmu dan cara - cara tertentu. Kaitannya dengan kasus Poligami di lingkungan Peradilan Agama yang Putusannya memperbolehkan berpoligami sesuai dengan prosedur permohonan poligami berdasarkan ketentuan hukum yang berlaku, maka diperlukan pengkajian dan analisis yang mendalam dalam memahami amar putusan pengadilan agama tersebut, karena pada memori putusan banding di Pengadilan Tinggi Agama, Majelis Hakim menyatakan menolak (membatalkan) putusan sebelumnya. sebagaimana dinyatakan dalam konsideran putusan permohonan izin poligami tersebut, yang dapat dipersingkat sebagai berikut:29

a. Pemohon pria berusia 50 tahun dengan pekerjaan Notaris \& PPAT lewat kuasa hukumnya berdasar pada surat kuasa khusus yang didaftarkan lewat kpaniteraan dengan nomor register W29- A1/10/HK.03.4/II/2007 mengajukan permohonan izin poligami ke Pengadilan Agama Ternate;

b. Yang menjadi termohon adalah Isteri sahnya seorang Wanita berusia 45 Tahun;

c. Pemohon melalui surat permohonan tertanggal 17 Februari 2007 yang telah terdaftar melalui Kepaniteraan Pengadilan Agama Ternate No 41/Pdt.G/2007/PA.Tte tertanggal 2007 momohon untuk diizinkan melakukan poligami (nikah lagi) dengan alasan yang dapat bahwa sang Isteri (Termohon) tidak dapat memberikan keturunan (anak) setelah pernikahan mereka berdua selama kurang-lebih 18 tahun, menurut saksi yang dihadirkan dalam persidangan pada tahun 2005 pemohon dan termohon pergi ke jawa untuk melakukan pengobatan naming belum membuahkan hasil, dan pemohon sudah memiliki pacar (kekasih) dan sudah berhubungan selama kuran/lebih 1 tahun;

d. Pemohon meminta kepada Ketua Pengadilan Agama Cq. Majelis Hakim agar mengabulkan permohonan untuk seluruhnya, dan menetapkan pemberian izin kepada pemohon untuk menikah dan kawin lagi;

${ }_{29}$ Pengadilan Agama Kelas 1B Ternate, Putusan Pengadilan Agama Ternate NO : 41/Pdt.G/2007/PA.Tte Tentang Permohonan Perkara Izin Poligami (Indonesia, 2007). 
e. Pengadilan telah memanggil kedua belah pihak dimana pemohon diwakili oleh kuasa hukumnya, sementara termohon menghadap ke pengadilan sendiri;

f. Pengadilan meminta kepada Pemohon lewat kuasa hukumnya mempertimbangkan Kembali keinginannya, dengan memberikan pandangan atas segala resiko dan konsekwensi.

g. Pemohon tetap pada permohonannya agar dapat diizinkan untuk menikah dan kawin lagi;

h. Termohon menjawab lewat jawaban tertulis bahwa:

1) Benar bahwa pemohon dan termohon telah menjalani rumah tangga selama 18 tahun dan tidak dikaruniai anak (keturunan);

2) Termohon tidak mengakui telah melakukan pemeriksaan secara medis, sehingga tidak diketahui secara jelas apakah yang tidak dapat menghasilkan keturunan termohon ataukah pemohon;

3) Termohon mengakui bahwa Islam memungkinkan seorang laki-laki untuk menikah lebih dari satu kali asalkan dapat berlaku adil, sedangkan Pemohon tidak berlaku adil dan cenderung lebih memihak kekasihnya (calon Isterinya);

i. Selain jawaban tertulis dari Termohon, jawaban lisan dari termohon kepada Pengadilan menyatakan bahwa Termohon tidak keberatan Pemohon menikah lagi, asalkan jangan menikah dengan calon isterinya yang ada sekarang, karena perempuan tersebut masih ada hubungan keluarga dengan Termohon meskipun keluarga jauh;

j. Adapun alat bukti tertulis dari Pemohon adalah:

1) Fotocopy buku kutipan Akta Nikah No. 20/1988 ( bukti P-1 ) yang dikeluarkan oleh Kepala Kantor Urusan Agama Kecamatan Ternate Selatan tanggal 16 januari 1988, telah dicocokkan sesuai dengan aslinya, bermeterai cukup ( bukti P-1 );

2) Surat keterangan penghasilan No. 470/47/2007 atas nama Pemohon; yang dikeluarkan oleh Kepala Kelurahan Takoma tanggal 26 maret 2007 cukup ( bukti P-2 ); 
3) Surat pernyataan bersedia berlaku adil yang ditanda tangani oleh Pemohon tertanggal 23 maret 2007 cukup ( P-3 ).

k. Selain ketiga alat bukti, Pemohon juga mengajukan 3 orang saksi diantaranya:

1) Teman Kerja Calon Isteri Pemohon (Pegawai Kantor Notaris dan PPAT)

2) Kenalan Pemohon;

3) Adik Kandung Pemohon;

1. Termohon menerima keterangan saksi 1 dan 2, namun menolak keterangan saksi ke tiga;

m. Termohon tetap tidak menyetujui permohonan dari Pemohon;

n. Perimbangan Hukum dari Majelis Hakim sebagai berikut:

1) Pengadilan Agama bertugas dan berwenang Memeriksa, Memutus, dan Menyelesaikan Perkara ditingkat Pertama antara orang - orang yang beragama Islam termasuk perkara dibidang Perkawinan (Poligami).

2) Majelis hakim telah memberi nasehat kepada pemohon agar mengurungkan niatnya, namun pemohon tetap pada pendiriannya;

3) Berdasarkan bukti P-1 Pemohon dan termohon adalah suami-isteri yang sah;

4) Pemohon memohon izin menikah lagi karena sudah 18 tahun membina rumah tangga namun belum dikarunai anak, dan telah 1 tahun membina hubungan (pacarana) dengan seorang Wanita;

5) Termohon memberikan keterangan dalam jawaban dan duplik bahwa pada pokoknya termohon tidak keberatan pemohon menikah lagi asal janga dengan Wanita yang sekarang menjadi calon isterinya sebab masih ada hubungan kekerabatan dengan termohon;

6) Termohon mengakui telah menikah 18 tahun namun belum dikaruniai keturunan;

7) penolakan yang diajukan secara oleh termohon, Majelis Hakim menilai penolakan tersebut tidak berdasarkan hukum, karena 
penolakan tidak didasari atas bukti - bukti yang kuat, selain itu telah nyata bahwa antara pemohon dengan calon isteri pemohon tidak ada hubungan nasab, sesusuan ataupun semenda, demikian pula antara calon isteri Pemohon dengan Termohon tidak ada hubungan yang menyebabkan tidak sahnya Perkawinan antara Pemohon dengan calon isteri Pemohon, sebaliknya berdasarkan fakta - fakta yang ada bahwa selama Pemohon membina rumah tangga dengan Termohon kurang lebih 18 tahun, tidak dikaruniai keturunan, sementara pemohon sangat mendambakan keturunan dari darah dagingnya sendiri, dimana hal ini merupakan naluriah bagi setiap manusia, maka berdasarkan fakta - fakta tersebut majelis Hakim berpendapat bahwa alasan permohonan pemohon setidaknya telah sejalan dan memenuhi syarat alternatif sebagaimana kehendak pasal 4 ayat (2) sub (a) UU Perkawinan No. 1 tahun 1974 junto Pasal 57 ayat (1) sub (a) KHI dimana Poligami tetap diperbolehkan slama memenuhi syarat formil dan sudah sesuai dengan aturan hukum yang berlaku;

8) pemohon telah menyatakan kesanggupannya untuk berlaku adil dan mampu menjamin keperluan hidup isteri - isteri dan anak - anak mereka sebagaimana tertuang dalam bukti P-2 dan bukti P-3, maka olehnya itu Majelis Hakim berpendapat bahwa permohonan pemohon secara formil telah memenuhi syarat komulatif sebagaimana kehendak pasal 5 ayat (1) UU Perkawinan No. 1 tahun 1974 junto pasal 55 ayat (2) dan pasal 58 ayat (1) KHI;

9) Permohonan telah menjalin hubungan cinta dengan calon isteri Pemohon (Fahima) selama 1 tahun, olehnya demi menghindari terjadinya kemudharatan yang lebih besar baik dari Pemohon dan calon isteri Pemohon maupun demi keutuhan rumah tangga Pemohon dengan Termohon, maka Majelis Hakim berpendapat bahwa jalan keluar yang terbaik adalah Pemohon menikah yang kedua kalinya dengan calon isteri Pemohon tersebut; 
10) Antara pemohon dengan calon isteri pemohon (Calon Isteri Pemohon) tidak ada hubungan darah/nasab atau susuan maupun semenda yang menghalangi dilangsungkannya perkawinan diantara keduanya, demikian pula calon isteri pemohon tidak terikat tali perkawinan dengan laki - laki lain, dimana telah sesuai dengan ketentuan pasal 8 dan pasal 9 UU No. 1 tahun 1974 junto pasal 39 dan 40 KHI;

11) berdasarkan atas segenap pertimbangan tersebut diatas, maka majelis Hakim menilai Permohonan Pemohon sudah cukup beralasan sehingga patut dikabulkan dengan menerapkan pasal 3 ayat (2), pasal 4 dan pasal 5 ayat (1) UU No. 1 Tahun 1974 junto pasal 55, 56, 57 dan 58 KHI serta dengan memperhatikan dalil - dalil dalam (Q.S An-Nisa :3)

12) berdasarkan pasal 89 ayat (1) UU No. 7 tahun 1989, pemohon dibebani untuk membayar biaya perkara yang besarnya sebagaimana tercantum dalam diktum putusan ini :

a) Memperhatikan pasal - pasal dari peraturan perundang undangan yang berlaku serta dalil - dalil syar'i yang berhubungan dengan perkara ini (putusan tingkat petama):

(1) Mengabulkan permohonan pemohon;

(2) Menetapkan, memberi izin kepada pemohon Faruk sebagai pemohon untuk menikah yang kedua kali dengan sorang perempuan bernama Fahima sebagai calon Isteri Pemohon;

(3) Membebankan kepada pemohon untuk membayar biaya perkara sebesar Rp. 216.000;- (dua ratus enam belas ribu rupiah);

Alasan pengabulan Majelis Hakim Pengadilan Agama Ternate terhadap permohonan izin poligami di atas dapat diuraikan secara sederhana, sebagai berikut:

a. Isteri tidak dapat memberikan keturunan;

b. Suami telah memiliki kekasih (calon Isteri) dan dikhawatirkan akan mengakibatkan kemudharatan; 
c. Calon isteri bukan orang yang dilarang untuk dinikahi (memiliki hubungan Nasab) dan masih perawan (tidak dalam ikatan perkawinan);

d. Suami dianggap memiliki penghasilan yang cukup untuk menafkahi para isteri;

e. Suami dianggap dapat berbuat adil;

Namun faktanya majelis hakim belum memeriksa bukti medis yang menyatakan bahwa yang bermasalah dengan "kesuburan" adalah pihak isteri sehingga menjadi "alasan pembenar" untuk dilakukannya poligami.

2. Analisis Putusan Pengadilan Tinggi Agama Maluku Utara Nomor : 12/Pdt.G/2007 PTA .MU Yang Membatalkan Putusan Pengadilan Agama Ternate NO : 41/Pdt.G/2007/PA.Tte Tentang Permohonan Perkara Izin Poligami.

Secara ringkas putusan pengadilan tinggi agama maluku utara Nomor : 12/Pdt.G/2007 PTA .MU, dapat diuraikan sebagai berikut:

a. Menimbang bahwa oleh karena Pemohon Banding yang diajukan oleh pembanding/Termohon telah sesuai dalam tegang waktu dengan caracara sebagaimana yang telah ditentukan menurut ketentuan perundangundangan maka permohonan banding tersebut dapat dinyatakan diterima. Menimbang bahwa perkara permohonan yang diajukan oleh pemohon atau pebanding pada tinggkat pertama tertanggal 17 Februari 2007 yang telah terdaftar di kepaniteraan Pengadilan Agama Ternate dengan Register Nomor perkara 41/Pdt.G/2007/PA.Tte adalah jenis Perkara Ijin Poligami, sedangkan permohonan ijin poligami adalah termasuk perkara yang bersifat Voluntair, sehingga perkara tersebut bersifat sepihak yakni hanya ada pihak Pemohon saja dan tidak ada orang lain yang ditarik sebagai Pemohon/Tergugat.

b. Menimbang bahwa dalam Permohonan Ijin Poligami Pemohon atau Terbanding tidak pernah menyatakan siapa calon istri keduanya sedangkan dalam berita acara persidangan muncul seorang yang bernama yang dianggap sebagai calon istri kedua Pemohon atau terbanding telah terjalin hubungan asmara (pacaran) dengan Pemohon atau Terbanding 
maka majelis hakim Pengadilan tinggkat banding berpendapat bahwa Permohonan Ijin Poligami Pemohon atau Terbanding dinyatakan (Obscur Liber).

c. Menimbang bahwa dengan memperhatikan pada surat kuasa prinsipal tertanggal 16 Februari 2007 yang diberikan kepada kausa hukumnya Rahman Mahfud SH tidak pula menyebutkan siapa calon istri kedua Pemohon/terbanding sehingga Permohonan Pemohon/Terbanding dinyatakan Kabur (Obcur Liber).

d. Menimbang bahwa berdasrkan alasan-alasan tersebut diatas maka putusan Pengadilan Agama No 41/Pdt.G/2007/PA.Tte tertanggal 24 April 2007 yang bertetapan dengan tanggal 6 Rabiull Tsani 1428 H haruslah dibatalkan dan Pengadilan Tinggi Agama akan mengadili sendiri sebagaimana bunyi amar putusan ini.

e. Amar Putusan

1) Menyatakan bahwa permohonan banding atau termohon dapat diterima.

2) Membatalkan putusan PA. TTE NO 41/Pdt.G/2007/PcA.Tte tertanggal 24 April 2007 yang bertetapan dengan tanggal 6 Rabiull Tsani $1428 \mathrm{H}$ dan dengan mengadili sendiri menyatakan permohonan Pemohon tidak dapat diterima (NO).

3) Membebankan Kepada Pemohon untuk membayar biaya perkara pada tinggkat pertama sebesar Rp. 216.000,00 (dua ratus enam belas ribuh rupiah).

4) Membebankan kepada Termohon / pembanding untuk membayar biaya perkara tinggkat banding sebesar Rp. 150, 000, 00 (seratus lima puluh ribuh rupiah).

Berdasarkan uraian diatas, menurut Penulis, dengan memperhatikan kronologis putusan No. 12/Pdt.G/2007/PTA.MU serta alasan - alasan berdasarkan hasil wawancara dengan Majelis Hakim PTA yang membatalkan putusan PA No; 41/Pdt.G/2007/PA.Tte dengan berbagai macam dalil 
pertimbangan yang dapat membatalkan suatu putusan tingkat pertama. Menurut analisis penyusun, apabila dalam penyelesaian perkara yang bersifat "contentiosa" sah-sah saja dalam pandangan hukum acara perdata berdasarkan HIR dan RBG serta peraturan hukum lainnya yang mengatur tentang hal tersebut, karena ternyata masih ada cela upaya hukum lainnya yang berlaku dan dapat dipergunakan sebagai dalil untuk membatalkan dan menolak atauoun mengakhiri suatu putusan tingkat pertama yang dapat dibanding ialah "Putusan Akhir" sesuai kekuasaan kompetensinya. Sedangkan dalam penyelesaiain perkara yang bersifat "Voluntair" modulnya penetapan tidak dilakukan upaya banding oleh PTA, tetapi langsung pada Tingkat Kasasi Mahkamah Agung.

Ditegaskan dalam pasal 9 UU No. 20 tahun 1947, bahwa Putusan PN yang bukan putusan akhir, hanya dapat dimintai banding bersama-sama dengan putusan akhir. Ketentuan ini sama dengan apa yang dicantumkan dalam pasal 190 HIR atau pasal 201 RBG. Yang dimaksud dengan putusan akhir atau end vonnis ialah putusan yang mengakhiri sengketa secara keseluruhan. Boleh saja putusan akhir bersifat "Negatif" dan boleh "Positif".

Putusan akhir yang bersifat negatif ialah putusan yang belum menyentuh pokok perkara yang dijatuhkan berdasarkan alasan formal yang bisa berupa kompetensi absolut atau relatif, obscur libel, nebis in idem, atau error in persona. Dan dapat pula putusan akhir yang bersifat positif dalam bentuk pengabulan atau penolakan gugat

Berdasarkan konsideran putusan dan tanggapan Majelis Hakim PTA tersebut diatas, menurut hemat penyusun putusan PTA No; 12/Pdt.G/2007/PTA.MU yang membatalkan putusan PA No; 41/Pdt.G/2007/PA-Tte tersebut adalah keliru, karena perkara permohonan izin poligami dalam bentuk "voluntair" tidak dapat dibanding, tetapi langsung di kasasi. Sedangkan putusan Majelis Hakim PTA yang membatalkan Putusan PA dan menyatakan permohonan pemohon tersebut dinyatakn "Kabur" dan tidak dapat diterima karena tidak memenuhi salah satu unsur formil dalam hukum acara perdata yang seharusnya dipatuhi oleh pemohon dan kuasa pemohon berdasarkan ketentuan pasal $8 \mathrm{Rv}$, dan pasal 123 HIR, 147 RBG. 
Kemudian formulasi surat "kuasa Khusus" dipertegas lagi dalam surat edaran Mahkamah Agung (SEMA) tanggal 23 januari 1971 tentang syarat-syarat sahnya surat kuasa khusus adalah merupakan perkara yang bersifat "contentiosa" yang dapat dibanding dan diputus oleh majelis Hakim PTA.

Dari Kerangka normatif hukum positif Negara RI pada dasarnya adalah aturan yang diciptakan atas dasar kepentingan negara mengatur kehidupan masyarakat agar tertib, damai dan aman sesuai dengan asas keadilan, kemanfaatan, dan kepastian hukum bukanlah hal yang mudah karena segala permasalahan semuanya telah diatur baik dalam bentuk hukum tertulis maupun hukum yang tidak tertulis. Menurut Abdul Ghofur Anshori, dalam pidato pengukuhan guru besar dengan judul Orientasi Nilai Filsafat Hukum Keluarga Refleksi UU No. 1 tahun 1974 tentang perkawinan, dan “ dalam surat (QS. AnNisa : 3), sebetulnya merupakan pembatasan dalam perkawinan pada bentuk perkawinan monogami. Perintah untuk menikahi wanita lebih dari satu, bukan perintah yang bersifat imperatif melainkan bersifat fluktuatif ketika kita tidak mampu berlaku adil kepada perempuan yatim yang kita nikahi, karena dalam ayat yang lain (QS. An-Nisa : 2) tersebut, tuhan melarang kita untuk menukar dan memakan harta anak yatim. Sedangkan nikahi wanita yang bukan anak yatim pun lagi-lagi dibatasi dengan jumlah seorang saja, ketika kita tidak mampu berlaku adil. Keadilan merupakan hal mutlak dalam kehidupan keluarga oleh karena itu perintah menikahi seorang saja lebih kuat dari pada lebih dari seorang, walaupun dalam hal ini Islam memberikan peluang kepada seorang laki-laki untuk menikah lebih dari satu dengan syarat yang berat yaitu mampu berlaku adil. Sehingga dengan demikian, peluang ini jangan dijadikan alasan legalitas yang bersifat imperatif terhadap keberlangsungan Praktik Poligami" 30

Poligami bukanlah merupakan hal yang mudah walaupun secara jelas telah dinyatakan dalam Al-Qur'an dan Hadist sebagai pengecualian dengan syarat syarat yang berat. Namun dalil Tuhan dan Nabi tersebut masih bersifat umum, dalam arti, pertama; dibolehkan bagi seorang suami untuk berpoligami asalkan

30 Abdul Ghofur Anshori and Sobirin Malian, Membangun Hukum Di Indonesia ( Pidato Pengukuhan Guru Besar Ilmu Hukum ) (Yogyakarta: Total Media, 2008). 
sanggup berbuat adil serta mampu memenuhi semua persyaratan yang telah ditentukan oleh UU No. 1 tahun 1974 dan KHI, dan, kedua; bagi seorang suami yang sanggup berpoligami tetapi tidak dapat memenuhi salah satu persyaratan alternatif maupun komulatif sesuai ketentuan hukum yang berlaku maka haram hukumnya untuk berpoligami karena takut suami dapat berbuat aniaya serta menyengsarakan isteri-isteri dan anak-anaknya kelak dikemudian hari.

Berdasarkan pembahasan dan analisa kedua putusan yang kontradiktif tersebut diatas, menurut hemat penyusun telah sesuai dengan ketentuan hukum yang berlaku (UU No. 1 tahun 1974 dan KHI), Namun pada putusan PA Ternate No: 41/Pdt.G/2007/PA.Tte tidak mengungkapkan secara jelas asal mula perkara permohonan izin poligami tersebut termasuk jenis perkara yang bersifat "Voluntair" atau "Contentiosa" menurut analisis penyusun putusan Majelis Hakim PA tersebut, mengadili dengan putusan "menetapkan" atau dengan kata lain, berarti termasuk ciri - cirinya perkara "Voluntairr". Tetapi duduk perkara dalam konsideran putusan PA tersebut, terdapat para pihak yang ditarik, yaitu isteri pertama sebagai termohon yang menolak seluruh permohonan pemohon dan menyatakan permohonan pemohon tidak dapat diterima serta termohon menambahkan keterangan yang pada pokoknya bahwa termohon tidak keberatan pemohon menikah lagi, asalkan jangan menikah dengan calon isterinya yang ada sekarang karena perempuan tersebut masih ada hubungan keluarga dengan termohon meskipun keluarga jauh. Selain itu pula pemohon juga mengajukan saksi-saksi sebagai " obyek " yang ditarik dalam perkara permohonan izin poligami. Menurut analisis penyusun, perkara permohonan izin poligami telah mengandung sengketa karena ada para pihak yaitu "isteri pertama" dalam konsideran putusan PA. Oleh karena itu, seharusnya Majelis Hakim PTA Maluku Utara lebih jeli melihat asal mula kasus " Permohonan atau Gugatan " tersebut, sehingga tidak terjadi kekeliruan dalam hal menerima perkara, ataupun melimpahkan perkara tersebut ke tingkat kasasi yang menjadi wewenang MA.

Hasil pemeriksaan perkara tingkat banding atau sering disebut sebagai pemeriksaan terakhir yaitu oleh (Judex Facte) menurut asasnya pemeriksaan dapat dilakukan dalam dua tahap, yaitu pertama; pemeriksaan terhadap duduk 
perkaranya, dan kedua; tahap penelitian tentang penerapan hukumnya atas fakta - fakta yang dianggap telah terbukti. Pemeriksaan tentang duduk perkara atau fakta-fakta berakhir pada tingkat banding. Majelis Hakim Pengadilan Tinggi Agama menilai Putusan Pengadilan Agama Ternate No : 41/Pdt.G/2007/PA.Tte tentang perkara Permohonan Izin Poligami adalah termasuk perkara yang bersifat "Voluntair", yakni hanya sepihak, yaitu pihak Pemohon saja tidak ada orang lain yang ditarik sebagai pihak Termohon/ Tergugat, menurut hemat penyusun kalau demikian seharusnya Majelis Hakim PTA, tidak menerima upaya banding, tetapi langsung di Kasasi ke Mahkamah Agung.

Dengan demikian, pada kenyataannya berdasarkan kosideran putusan PTA tersebut, ternyata dalam Pertimbangan Majelis Hakim Pengadilan Tinggi Agama menilai Pemohon tidak pernah menyatakan siapa calon isteri kedua Pemohon/ Terbanding, namun dalam berita acara persidangan muncul seorang yang bernama Fatima dan Fahima sebagai calon isteri kedua Pemohon / Terbanding yang telah menjalin hubungan cinta (Pacaran) dengan Pemohon / Terbanding, maka Majelis Hakim Pengadilan tingkat banding berpendapat bahwa permohonan izin poligami Pemohon / Terbanding dinyatakan kabur (obscur libel) . dengan memperhatikan pula surat kuasa Prinspal tertanggal 16 Februari 2007 yang diberikan kepada kuasanya tidak pula menyebutkan siapa calon isteri kedua Pemohon / Terbanding, sehingga Pemohonan Pemohon / Terbanding dinyatakan Kabur.

Berdasarkan alasan - alasan tersebut diatas, putusan pengadilan agama No: 41 /Pdt.G/2007/PA.Tte tertanggal 24 april 2007 M yang bertepatan dengan tanggal 6 Rabiul Tsani 1428 H haruslah dibatalkan dan Pengadilan Tinggi Agama akan mengadili sendiri sebagaimana bunyi amar :

1. Menyatakan bahwa permohonan banding Pembanding/Termohon dapat diterima.

2. Membatalkan Putusan PA Ternate No: 41/Pdt.G/2007/PA.Tte tertanggal 24 april 2007 M yang bertepatan dengan tanggal 6 Rabiul Tsani $1428 \mathrm{H}$ dan dengan mengadili sendiri menyatakan permohonan Pemohon tidak dapat diterima ( N.O); 
Berdasarkan Putusan Pengadilan Tinggi Agama tersebut, menurut analisis penulis dalam pertimbangan hukumnya sesuai duduk perkara dan fakta - fakta Majelis Hakim PTA menilai ternyata pada kenyataannya ada saksi-saksi serta calon isteri pemohon yang telah ditarik dalam perkara permohonan "Voluntair" oleh pemohon sebagai "obyek". Sedangkan isteri sah yaitu (isteri pertama) sesuai konsideran putusan sebagai termohon yang menolak permohonan pemohon sekaligus sebagai kunci pemberian izin kepada pemohon untuk berpoligami adalah sebagai "pihak" sehingga Majelis Hakim PTA berani mengambil langkah langkah untuk mengungkapkan calon isteri kedua pemohon sebagai "obyek" yang tidak mencantumkan identitasnya dalam berita acara permohonan, tetapi hanya disebutkan saja secara lisan pada saat penyerahan berkas permohonan, yang menurut pertimbangan Majelis Hakim PTA Permohonan Pemohon dinyatakan kabur (Obscur Libel). Kemudian putusannya membatalkan Putusan PA Ternate No: 41 /Pdt.G/2007/PA.Tte dan menyatakan permohonan Pemohon tidak dapat diterima (N.O); yang menurut penyusun dasar pertimbangan Majelis Hakim PTA tersebut adalah termasuk perkara permohonan yang bersifat "Contentiosa", yang dapat dibanding, bukan perkara permohonan yang bersifat "Volunter". Maka penulis menilai pertimbangan Majelis Hakim PTA mengatakan bahwa perkara Permohonan Izin poligami di PA tersebut bersifat "Volunter" adalah keliru.

Menurut analisis penulis, apabila putusan Majelis Hakim PA No: 41 /Pdt.G/2007/PA.Tte tersebut, termasuk perkara bersifat "Voluntair" maka tidak dapat dilakukan upaya banding, tetapi langsung dikasasi ke MA, tetapi kalau perkara tersebut bersifat "Contentiosa" maka dapat dilakukan upaya banding. Menurut hemat penyusun putusan Majelis Hakim PTA No: 12 /Pdt.G/2007/PTA.MU tersebut bukan putusan yang bersifat “Voluntair" tetapi bersifat "Contentiosa" karena dapat dilakukan upaya putusan banding oleh Majelis Hakim PTA. Berdasarkan kedua putusan tersebut, menurut pasal 59 Bab IX KHI terhadap penetapan ini, isteri atau suami dapat mengajukan Banding atau Kasasi. 


\section{E. Kesimpulan}

Majelis Hakim Pengadilan Agama Ternate, menerima Permohonan pada tingkat pertama yang di ajukan oleh Pemohon, dan dalam Amar Putusan No: 41/Pdt.G/2007/PA.Tte, Majelis Hakim mengabulkan Permohonan Izin Poligami dari si Pemohon dengan alasan duduk perkaranya sudah sesuai dengan aturan hukum yang berlaku dan telah memenuhi syarat formil.

Majelis Hakim Pengadilan Tinggi Agama Maluku Utara, menerima Permohonan Banding yang di ajukan oleh Termohon / Pembanding, namun dalam Amar Putusan No : 12/Pdt.G/2007/PTA.MU, Majelis Hakim Membatalkan Putusan Pengadilan Agama Ternate No : 41/Pdt.G/2007/PA.Tte yang menyatakan bahwa Permohonan Pemohon / Terbanding tidak dapat diterima ( N.O) atas pertimbangan Pemohon dan Kuasa Pemohon tidak menyebutkan identitas secara jelas nama calon Isteri Kedua Pemohon / Terbanding dalam Kontra Memori Banding sehingga Majelis Hakim Pengadilan Tinggi Agama Maluku Utara berpendapat bahwa Permohonan Pemohon dinyatakan kabur ( obscur libel ).

\section{Daftar Pustaka}

Abdurrahman. KHI Di Indonesia. Jakarta: Akademika Pressindo, 1992.

- - - Penjelansan Hukum-Hukum Allah (Syari'ah). Jakarta: Rajawali Pers, n.d.

Abidin, Slamet, and Aminuddin. Fikih Munakahat I. Bandung: Pustaka Setia, 1999.

- - - Fiqih Munakahat II. Bandung: Pustaka Setia, 2009.

Al-Asqalani, Ibn Hajar. Bulughul Maram Min Adillatil Ahkam. Edited by Muhammad Thalib. 2nd ed. Bandung: Gema Risalah Press, 1996.

Ali, Zainuddin. Hukum Perdata Islam Di Indonesia. Jakarta: Sinar Grafika, 2006.

Anshori, Abdul Ghofur. Filsafat Hukum. Yogyakarta: Gadjah Mada University Press, 2009.

- - - . Hukum Islam (Dinamika Dan Perkembangannya Di Indonesia). Yogyakarta:

Kreasi Total Media, 2008.

- - - Peradilan Agama Di Indonesia Pasca UU No. 3 Tahun 2006 Sejarah, Kedudukan

Dan Kewenangan. 1st ed. Yogyakarta: UII Press, 2007.

Anshori, Abdul Ghofur, and Sobirin Malian. Membangun Hukum Di Indonesia ( Pidato 
Pengukuhan Guru Besar Ilmu Hukum ). Yogyakarta: Total Media, 2008.

Basyir, Ahmad Azhar. Hukum Perkawinan Islam. Yogyakarta: UII Press, 1990.

Basyir, Ahmad Azhar, and Dkk. Pengadilan Agama Islam Dan KHI Dalam Tata Hukum

Indonesia. Edited by Moh. Mahfud MD. Yogyakarta: UII Press, 1993.

Departemen Agama RI. Al-Qur'an Dan Terjemahan. Jakarta: Pustaka Amani, 2006.

Direktorat Pembinaan Badan Peradilan Agama, Direktorat Jenderal Pembinaan

Kelembagaan Agama Islam. Kompilasi Hukum Islam, n.d.

Djalil, H. A. Basiq. Peradilan Agama Di Indonesia (Gemuruhnya Politik Hukum ( Hukum Islam, Hukum Barat, Dan Hukum Adat) Dalam Rentang Sejarah Pasang Surut Lembaga Peradilan Agama Hingga Lahirnya Peradilan Syariat Islam Di Aceh). Jakarta: Kencana, 2006.

Ghozali, Abdul Rahman. Fiqih Munakahat. Jakarta: Kencana Prenada Media Group, 2012.

Gusmiah, Islah. Mengapa Nabi Muhammad SAW Berpoligami ? Yogyakarta: Pustaka Marwa, 2007.

Harahap, Yahya. Hukum Perkawinan Nasional. Medan: Medan Zahir Trading Co, 1975.

Mahid, and Dkk. Sejarah Kerajaan Bungku. Yogyakarta: Ombak, 2012.

Nasional, Departemen Pendidikan. Kamus Besar Bahasa Indonesia. Jakarta: Balai Pustaka, 2003.

Nasution, Bahder Johan. Metode Penilitian Ilmu Hukum. Bandung: Mandar Maju, 2008.

Republik Indonesia, Presiden. Undang-Undang Nomor 1 Tahun 1974 Tentang

Perkawinan. Indonesia, 1974.

Rosyadi, Rahmat, and Sri Hartini. Advokat Dalam Perspektif Islam Dan Hukum Positif. Jakarta: Ghalia Indonesia, 2003.

Saebani, Beni Ahmad. Perkawinan Dalam Hukum Islam Dan UU ( Perspektif Figh

Munakahat Dan UU No. 1 Tahun 1974 Tentang Poligami Dan Problematikanya).

Bandung: Pustaka Setia, 2008.

Soemiyati. Hukum Perkawinan Islam Dalam Undang-Undang Perkawinan (UndangUndang Nomor 1 Tahun 1974 Tentang Perkawinan). 4th ed. Yogyakarta: Liberty, 
2003.

Tariga, Amir Nurudin Azhari Akmal. Hukum Perdata Islam Di Indonesia, Studi Kritis Perkembangan Hukum Islam Dan Fikih, UU No. 1 Tahun 1974 Sampai KHI. 3rd ed. Jakarta: Kencana, 2006.

Ternate, Pengadilan Agama Kelas 1B. Putusan Pengadilan Agama Ternate NO : 41/Pdt.G/2007/PA.Tte Tentang Permohonan Perkara Izin Poligami. Indonesia, 2007. Utomo, Setiawan Budi. Fiqih Aktual (Jawaban Tuntas Masalah Kontemporer). Jakarta: Gema Insani Press, 2003.

Winarno, Teguh Sri Rahardjo, and Abd. Muin Dj. Finarto. Buku Pintar Hukum (Strategi Praktis Menyelesaikan Masalah - Masalah Hukum). Yogyakarta: UII Press, 2007. 